\title{
PENGARUH PENERAPAN E-FILING, TINGKAT PEMAHAMAN PERPAJAKAN DAN KESADARAN WAJIB PAJAK TERHADAP KEPATUHAN WAJIB PAJAK DI KPP PRATAMA YOGYAKARTA
}

\author{
Wulandari Agustiningsih \\ Prodi Akuntansi Universitas Negeri Yogyakarta \\ Wulanagusti35@yahoo.com
}

\author{
Isroah \\ Staf Pengajar Jurusan Pendidikan Akuntansi Universitas Negeri Yogyakarta
}

\begin{abstract}
Abstrak : Pengaruh Penerapan E-Filing, Tingkat Pemahaman Perpajakan Dan Kesadaran Wajib Pajak Terhadap Kepatuhan Wajib Pajak Di Kpp Pratama Yogyakarta. Penelitian ini bertujuan untuk mengetahui (1) Pengaruh penerapan e-filing terhadap kepatuhan wajib pajak. (2) Pengaruh tingkat pemahaman perpajakan terhadap kepatuhan wajib pajak. (3) Pengaruh kesadaran wajib pajak terhadap kepatuhan wajib pajak. (4) Pengaruh penerapan $e$-filing, tingkat pemahaman perpajakan dan kesadaran wajib pajak terhadap kepatuhan wajib pajak. Populasi penelitian ini adalah Wajib Pajak pengguna $e$-filing di KPP Pratama Yogyakarta dengan sampel sebanyak 70 responden. Data penelitian ini diperoleh melalui kuesioner.Teknik pengambilan sampel menggunakan incidental sampling. Hasil penelitian ini menunjukan bahwa (1) Penerapan $e$-filing berpengaruh positif dan signifikan terhadap kepatuhan wajib pajak dengan nilai koefisien determinasi 0,454. (2) Tingkat pemahaman perpajakan berpengaruh positif dan signifikan terhadap kepatuhan wajib pajak dengan koefisien determinasi 0,444. (3) Kesadaran wajib pajak berpengaruh positif dan signifikan terhadap kepatuhan wajib pajak dengan nilaikoefisien determinasi 0,621. (4) Penerapan e-filing, tingkat pemahaman perpajakan dan kesadaran wajib pajak berpengaruh positif dan signifikan terhadap kepatuhan wajib pajak dengan Nilai F hitung lebih besar dari F tabel yaitu 59.820>3,94.
\end{abstract}

Kata kunci: Kepatuhan wajib pajak, e-filing, tingkat pemahaman perpajakan, kesadaran wajib pajak, perpajakan.

Abstract: The Effect Of Implementation E-Filing, Level Of Tax Understanding And Taxpayers Consciousness On Taxpayers Compliance In Kpp Pratama Yogyakarta. The purpose of this study was to determine: (1)The effect of implementation e-filing on compliance taxprayers. (2) The effect of level of tax understanding on compliance taxprayers. (3 )The effect of consciousness taxpayers on compliance taxpayers. (4) The effect of implementation e-filing, level of tax understanding and consciousness taxpayers on compliance taxpayers. The population in this study is e-filing user taxpayers in KPP Pratama Yogyakarta with samples 70 respondents. Data in this study were obtained through questionnaires. The sampling technique used incidental sampling. The results showed that: (1) The implementation e-filing has positive and significant effect on taxpayers compliance with value of coefficient determination 0,454. (2) The level of tax understanding has positive and significant effect on taxpayers compliance with value of coefficient determination 0,444 (3) The taxpayers consciousnesshas positive and significant effect on taxpayers compliance with value of coefficient determination 0,621. (4) The effect of implementation e-filing, level of tax understanding and taxpayers consciousness has positive and significant on taxpayers compliance with $F$ count larger than $F$ table is $59.820>3,94$.

Keywords: Taxpayers compliance, e-filing, level of tax understanding, taxpayers consciousness, taxation 


\section{JURNAL NOMINAL / VOLUME V NOMOR 2 / TAHUN 2016}

\section{PENDAHULUAN}

Salah satu sumber pendapatan negara terbesar adalah penerimaan pajak. Pajak digunakan oleh pemerintah untuk pembiayaan pembangunan nasional. Hal ini dilakukan untuk mensejahterahkan masyarakat. Peranan pajak dalam pembangunan nasional sangat dominan. Peranan dari pajak dapat dirasakan secara langsung maupun tidak langsung dalam kehidupan sehari-hari. Manfaat yang dirasakan dari pajak adalah fasilitas pendidikan, fasilitas transportasi, fasilitas kesehatan sarana dan prasarana umum. Pentingnya peran pajak dalam pembangunan membutuhkan peningkatan dalam penerimaan pajak.

Pajak didapat dari kontribusi masyarakat (Wajib Pajak) dengan menggunakan sistem self assessment. Sistem self assessment merupakan sebuah sistem reformasi yang dilakukan oleh Direktorat Jenderal Pajak. Sistem ini menggantikan sistem official assessment yang berlaku sebelumnya. Sistem self assessment adalah sistem dimana Wajib Pajak diberi kepercayaan untuk menghitung dan melaporkan sendiri pajak yang terutang oleh Wajib Pajak, sedangkan petugas pajak sendiri bertugas untuk mengawasinya. Hal itu berarti berhasil atau tidaknya sistem ini sangat ditentukan oleh kepatuhan sukarela para Wajib Pajak dan pengawasan yang optimal dari aparat pajak sendiri. Sistem ini sangat bergantung pada kesadaran Wajib Pajak dalam memenuhi kewajiban perpajakannya masih banyak Wajib Pajak yang tidak patuh untuk melaporkan dan membayar pajak.

Menurut data dari cnnindonesia.com Direktorat Jenderal Pajak (DJP) mencatat jumlah Wajib Pajak di Indonesia tahun 2014 sebanyak 60 juta individu dan 5 juta badan usaha. Namun dari jumlah tersebut, hanya 23 juta Wajib Pajak Orang Pribadi (WPOP) dan 550 ribu badan usaha yang taat membayar pajak. Jumlah masyarakat pemilik Nomor Pokok Wajib Pajak (NPWP) saat ini sekitar 28 juta orang, sementara yang patuh melaporkan Surat Pemberitahuan (SPT) baru sekitar 11 juta. Badan Pusat Statistik (BPS) mencatat pada 2013 terdapat sekitar 20 juta perusahaan yang beroperasi di Indonesia. Namun, berdasarkan analisis Direktorat Jenderal Pajak, baru sekitar 5 juta perusahaan yang wajib membayar pajak.

Berdasarkan data yang dipaparkan oleh ortax.org jumlah pelapor SPT tahun 2015 lebih rendah dibandingkan dengan tren pelaporan SPT PPh dalam empat tahun terakhir. Hingga penutupan pelaporan SPT tanggal 31 maret 2015, Wajib Pajak yang menyerahkan SPT $\mathrm{PPh}$ orang pribadi jumlahnya tidak mencapai target 10 juta orang. Pada tahun 2012 jumlah pelaporan SPT 9,22 juta dari 17,65 juta wajib pajak yang terdaftar. Pada tahun 2013 jumlah 


\section{JURNAL NOMINAL / VOLUME V NOMOR 2 / TAHUN 2016}

pelapor sebanyak 9,8 juta dari 17,73 Wajib

Pajak yang terdaftar, sedangkan pada tahun 2014 Wajib Pajak yang menyampaikan SPT sebanyak 10,78 juta dari 18,35 Wajib Pajak yang terdaftar.

Menurut Setiyaji dan Amir (2005), administrasi perpajakan diduga sebagai penyebab rendahnya tingkat kepatuhan Wajib Pajak di Indonesia yang berdampak pada tidak optimalnya penerimaan pajak. Perubahan kebijakan perpajakan tidak akan memuaskan hasilnya jika tidak diikuti dengan reformasi administrasi perpajakan. Administrasi perpajakan yang efektif harus menciptakan lingkungan yang mendorong Wajib Pajak secara sukarela mematuhi peraturan yang berlaku.

Direktorat Jenderal Pajak mencoba untuk memberikan pelayanan yang prima kepada para Wajib Pajak dan melakukan inovasi-inovasi dalam pelayanannya. Salah satu inovasi yang dilakukan oleh Direktorat Jenderal Pajak adalah dengan melakukan perubahan pada administrasi pelaporan perpajakan.Direktorat Jenderal Pajak membuat sebuah sistem yang lebih sederhana dalam pelaporan pajak denga $e$-filing .

Adanya sistem pelaporan pajak dengan menggunakan e-filing dapat memudahkan Wajib Pajak. Wajib Pajak dapat melaporkan SPTnya 24 jam selama 7 hari. Hal ini berarti wajib pajak dapat melaporkan SPTnya meskipun pada hari libur.Sistem ini sangat bermanfaat untuk wajib pajak yang tidak melapokan SPTnya dengan alasan sibuk. Selain itu, dengan adanya e-filing ini dapat mengurangi biaya yang ditimbulkan dari penggunaan kertas. Namun, faktanya masih banyak Wajib Pajak yang belum mengerti sepenuhnya cara melaporkan SPTnya secara elektronik, padahal banyak manfaat yang didapatkan apabila menggunakan $e$-filing ini.

Setiap Wajib Pajak yang terdaftar tentu memiliki Nomor Pokok Wajib Pajak (NPWP), dianggap sudah mengerti dan memahami mengenai peraturan perpajakan yang berlaku. Namun, menurut Ortax.org, dalam prakteknya masih banyak Wajib Pajak yang kurang paham tentang peraturan perpajakan bahkan masih ada Wajib Pajak yang tidak tahu sama sekali mengenai peraturan perpajakan yang berlaku. Masih ada beberapa Wajib Pajak yang tidak sepenuhnya memahami tentang peraturan perpajakan akan berdampak pada penerimaan pajak di Indonesia. Seorang Wajib Pajak dapat dikatakan patuh dalam kegiatan perpajakan apabila memahami secara penuh tentang peraturan perpajakan antara lain: mengetahui dan berusaha memahami Undang-Undang Perpajakan, cara pengisian formulir perpajakan, cara menghitung pajak, cara melaporkan SPT dan selalu membayar pajak tepat waktu.

Kesadaran wajib pajak dalam melakukan kewajiban perpajakannya masih rendah. Seperti yang dilansir dari tribunjogja.com, realisasi penerimaan pajak 


\section{JURNAL NOMINAL / VOLUME V NOMOR 2 / TAHUN 2016}

masyarakat Bantul di Kantor Pajak Pratama (KPP) Bantul pada tahun 2015 masih belum mencapai target. Masih kurangnya kesadaran masyarakat untuk membayar pajak menjadi sebab pencapaian target penerimaan pajak tahun 2015 turun banyak dari tahun 2014. Tahun 2014 pencapaian target penerimaan pajak sebesar $98 \%$ sedangkan untuk tahun 2015 hanya mencapai $85,5 \%$ dari target penerimaan pajak.

Ada beberapa penelitian yang dilakukan untuk mengetahui penerapan $e$ filing terhadap Kepatuhan Wajib Pajak. Hasil penelitian Nurul Afia Sari (2013) memaparkan bahwa penerapan sistem $e$-spt meningkatkan jumlah Wajib Pajak terdaftar yang menyampaikan SPT. Namun, penerapan sistem $e$-SPT tidak meningkatkan tingkat Kepatuhan Wajib Pajak. Penelitian yang dilakukan oleh Nurul Afia Sari berbeda dengan penelitian yang dilakukan oleh Sari Nurhidayah. Penelitian yang dilakukan oleh Sari Nurhidayah (2014) menyatakan bahwa penerapan e-filing berpengaruh positif terhadap kepatuhan Wajib Pajak. Adanya perbedaan penelitian dan belum adanya penelitian yang meneliti tentang penerapan $e$ filing, tingkat pemahaman perpajakan dan kesadaran Wajib Pajak di KPP Pratama Yogyakarta membuat peneliti tertarik untuk melakukan penelitian dengan judul 'Pengaruh Penerapan E-Filing, Tingkat Pemahaman Perpajakan Dan Kesadaran
Wajib Pajak Terhadap Kepatuhan Wajib

Pajak Di KPP Pratama Yogyakarta". METODE PENELITIAN

\section{Jenis Penelitian}

Penelitian ini menggunakan pendekatan deskriptif korelasional. Tujuan studi deskriptif adalah memberikan kepada peneliti sebuah riwayat atau menggambarkan aspek-aspek yang relevan dengan fenomena, perhatian dan perspektif seseorang, organisasi, orientasi industri atau yang lainnya (Uma Sekaran, 2007:158). Menurut Husein Umar (2011:25) penelitian korelasi adalah penelitian yang dirancang untuk menentukan tingkat hubungan variabelvariabe yang berbeda dalam satu populasi. Disini peneliti dapat mengetahui berapa besar variabel-variabel bebas terhadap variabel terikatnya serta besarnya arah hubungan yang terjadi.

\section{Waktu dan Tempat Penelitian}

Penelitian ini dilaksanakan di KPP Pratama Yogyakarta.Waktu pelaksanaan penelitian bulan Desember 2015 hingga Januari 2016.

\section{Definisi Operasional Variabel Penelitian}

a) Variabel Dependen (Y)

Kepatuhan Wajib Pajak adalah suatu keadaan dimana Wajib Pajak memenuhi segala kewajiban perpajakannya seperti: mendaftarkan diri untuk mendapatkan NPWP; melaporkan usahanya untuk dikukuhkan sebagai PKP; menghitung pajak terhutang; mengisi dengan benar SPT dan menyelenggarakan pembukuan. Serta 


\section{JURNAL NOMINAL / VOLUME V NOMOR 2 / TAHUN 2016}

melaksanakan seluruh hak perpajakannya seperti: mengajukan surat keberatan; menerima tanda bukti pemasukan SPT; melakukan pembetulan SPT; mengajukan permohonan penundaan penyampaian SPT; mengajukan permohonan penundaan atau pengangsuran pembayaran pajak; meminta pengembalian kelebihan pembayaran pajak; mengajukan permohonan penghapusan pengurangan sanksi; memberi kuasa kepada orang untuk melaksanakan kewajiban pajaknya dan meminta bukti pemotongan atau pemungutan pajak.

b) Variabel Independen (X)

$$
\text { E-filling adalah suatu cara }
$$
penyampaian SPT (Masa dan Tahunan) atau Pemberitahuan PerpanjanganSPT Tahunan yang dilakukan secara online yang real time melalui Penyedia JasaAplikasi atau Application Service Provider (ASP).

Tingkat pemahaman perpajakan adalah tingkatan pengetahuan dan pikiran Wajib Pajak atas kewajiban perpajakannya untuk memberikan kontribusi kepada Negara dalam memenuhi keperluan pembiayaan dan pembangunan nasional guna tercapainya keadilan dan kemakmuran.

Kesadaran Wajib Pajak adalah pemahaman yang mendalam pada seseorang atau badan yang terwujud dalam pemikiran, sikap, dan tingkah laku untuk melaksanakan hak dan kewajiban perpajakan sesuai dengan ketentuan peraturan perundang-undangan karena memahami bahwa pajak sangat penting untuk pembiayaan nasional.

\section{Prosedur}

Penelitian ini dilakukan dengan menyebar kuesioner (angket) ke Wajib Pajak di KPP Pratama Yogyakarta. Prosedur Penelitian sebagai berikut:

a) Peneliti memilih responden yang akan diteliti yaitu wajib pajak pengguna $e$ filing.

b) Sebelum pelaksanaan penelitian peneliti bermaksud untuk menjelaskan tujuan penelitian pada responden.

c) Setelah responden mengerti tujuan, peneliti memberikan penjelasan mengenai cara-cara pengisisan kuesioner.

d) Responden diminta untuk mengisi kolom identitas seperti nama, jeis kelamin, lama waktu menggunakan $e$-filing dan lain-lain.

e) Selanjutnya responden diminta untuk mencentang jawaban pada salah satu kolom yaitu jawaban sangat setuju, setiuju, tidak setuju dan sangat tidak setuju.

f) Jika ada tesponden belum mengerti atau ada pertanyaan yang belum jelas maka dapat ditanyakan pada peneliti.

\section{Populasi Dan Sampel}

Populasi dalam penelitian ini adalah Wajib Pajak yang sudah menggunakan $e$ filing di KPP Pratama Yogyakarta.Pemilihan populasi tersebut karena Wajib Pajak tersebut pernah menggunakan e-filing 


\section{JURNAL NOMINAL / VOLUME V NOMOR 2 / TAHUN 2016}

sehingga dapat dijadikan responden untuk mengetahui Kepatuhan Wajib Pajak di KPP Pratama Yogyakarta.Wajib Pajak yang terdaftar sebagai Wajib Pajak e-filing di KPP Pratama Yogyakarta berjumlah 7.835 orang. Teknik pengambilan sampel yang digunakan dalam penelitian ini adalah sampling insidental. Sampling insidental adalah teknik penentuan sampel berdasarkan kebetulan, yaitu siapa saja yang secara kebetulan atau insidental bertemu dengan peneliti dapat digunakan sebagai sampel, bila dipandang orang yang kebetulan ditemui cocok sebagai sumber data. Penentuan jumlah sampel dalam penelitian menggunakan pendapat Gay. Menurut Husein Umar (2011:79) pendapat Gay menyatakan bahwa ukuran sampel yang dapat di terima berdasarkan pada desain penelitian yang digunakan, dimana penelitian dengan metode deskriptif-korelasional memiliki ukuran sampel minimal 30 subjek. Sampel yang digunakan dalam penelitian ini berjumlah 70 subjek.

\section{Teknik Pengumpulan Data}

Data diperoleh dengan memberikan angket atau kuesioner pada responden. Pembagian kuesioner atau angket dilakukan oleh peneliti kepada Wajib Pajak di KPP Pratama Yogyakarta. Sebelum pelaksanaan penelitian peneliti bermaksud untuk menjelaskan tujuan penelitian pada responden. Setelah responden mengerti tujuan, peneliti memberikan penjelasan mengenai cara-cara pengisisan kuesioner. Responden diberikan waktu dan diminta untuk mengisi data sesuai dengan yang tercantum dalam kuesioner. Jika Wajib Pajak yang menjadi responden belum mengerti atau ada pertanyaan yang belum jelas maka dapat ditanyakan pada peneliti.

\section{Uji Coba Instrumen}

Data yang digunakan dalam uji coba instrumen diambil dari Wajib Pajak pengguna e-filing di KPP Pratama Yogyakarta. Pengambilan data menggunakan kuesioner dengan skala likert yang untuk mengukur Kepatuhan Wajib Pajak di KPP Pratama Yogyakarta (Y), penerapan $e$-filing $\left(\mathrm{X}_{1}\right)$, tingkat pemahaman perpajakan $\left(\mathrm{X}_{2}\right)$ dan kesadaran Wajib Pajak $\left(\mathrm{X}_{3}\right)$. Uji coba instrumen dilakukan dengan menyebar 30 kuesioner kepada wajib pajak pengguna e-filing di KPP Pratama Yogyakarta.

a) Uji Validitas Data

Uji validitas data menggunakan pendekatan Content (face) validity.Nilai validitas data dicari dengan menggunakan rumus korelasi product moment.Perhitungan ini menggunakan bantuan komputer program SPSS 20. Perhitungan dilakukan dengan menggunakan Scale-reliability analysis pada tabel item total statistic dengan item corrected item total correlation (Sugiyono \& Agus, 2015:388). 
Pertanyaan/pernyataan kuesioner dikatakan valid apabila nilai $r_{i}>\mathrm{r}$ tabel.

b) Uji Reliabilitas Data

Uji reliabilitas data menggunakan pendekatan reliabilitas konsistensi internal. Untuk mengukur konsistensi internal peneliti menggunakan salah satu teknik statistik yaitu Combarch's alpha. Menurut Husein Umar (2011:173) suatu variabel dikatakan valid apabila nilai Combarch's alpa $>0,70$. Perhitungan ini dilakukan dengan bantuan komputer program SPSS 20.

\section{Teknik Analisis Data}

\section{a) Analisis Regresi Sederhana}

Regresi sederhana didasarkan pada hubungan fungsional ataupun kausal satu variabel independen dengan satu variabel dependen. Persamaan umum regresi linear sederhana $\hat{Y}=a+b X$. Uji t dilakukan untuk menguji signifikansi konstanta dan variabel bebas dengan satu variabel terikat.

\section{b) Analisis Regresi Berganda}

Regresi linear berganda digunakan untuk mengetahui pengaruh antara variabel bebas dengan variabel terikat, yaitu: $e$ filing, tingkat pemahaman perpajakan dan kesadaran Wajib Pajak terhadap Kepatuhan Wajib Pajak di KPP Pratama Yogyakarta. Persamaan umum regresi linear berganda $\mathrm{Y}=\mathrm{a}+b_{1} X_{1}+b_{2} X_{12}+$ $b_{3} X_{3}$. Uji $\mathrm{F}$ hitung dimaksudkan untuk menguji model regresi atas pengaruh seluruh variabel independen yaitu: $X_{1}, X_{2}, X_{3}$ secara simultan terhadap variabel dependen.

HASIL PENELITIAN DAN PEMBAHASAN

\section{Statistik Deskriptif}

Responden data dalam penelitian ini berjumlah 70 Wajib Pajak pengguna $e$ filing.Analisis data statistik deskriptif yang disajikan dalam penelitian ini meliputi harga rerata Mean (M), Modus (Mo), Median (Me), dan Standar Deviasi (SD). Mean merupakan rata-rata, modus merupakan nilai variabel atau data yang mempunyai frekuensi tinggi dalam distribusi. Berikut ini adalah hasil analisis statistik deskriptif dari data penelitian:

Tabel.1 Hasil Analisis Deskriptif

\begin{tabular}{ccccc}
\hline KET & $\mathbf{Y}$ & $\boldsymbol{X}_{\mathbf{1}}$ & $\boldsymbol{X}_{\mathbf{2}}$ & $\boldsymbol{X}_{\mathbf{3}}$ \\
\hline Min & 18 & 57 & 26 & 14 \\
\hline Max & 36 & 92 & 40 & 24 \\
\hline M & 30,8 & 80,31 & 32,47 & 20,73 \\
\hline Mo & 27 & 69 & 40 & 24 \\
\hline Me & 30 & 83 & 35 & 22 \\
\hline SD & 4,299 & 10,140 & 4,373 & 2,909
\end{tabular}

Sumber: data primer yang diolah (2016) 


\section{JURNAL NOMINAL / VOLUME V NOMOR 2 / TAHUN 2016}

\section{Uji Asumsi Klasik}

\section{a) Uji Normalitas}

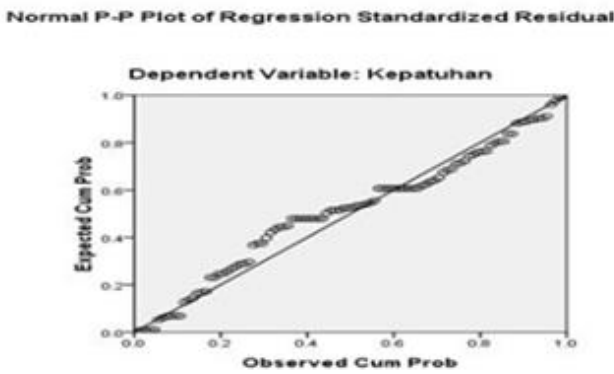

Gambar. 1 Uji Normalitas

Gambar diatas merupakan Hasil dari pengolahan data uji normalitas dengan program SPSS Versi 20. Dengan melihat tampilan pada grafik normal plot terlihat titik-titik menyebar di sekitar garis diagonal dan mengikuti arah garis diagonal. Hal ini menunjukkan bahwa model regresi dalam penelitian ini memenuhi asumsi normalitas.

\section{b) Uji Linearitas}

Hasil pengolahan data uji linearitas dengan program SPSS Versi 20 adalah sebagai berikut:

Tabel 2. Hasil Uji Linearitas

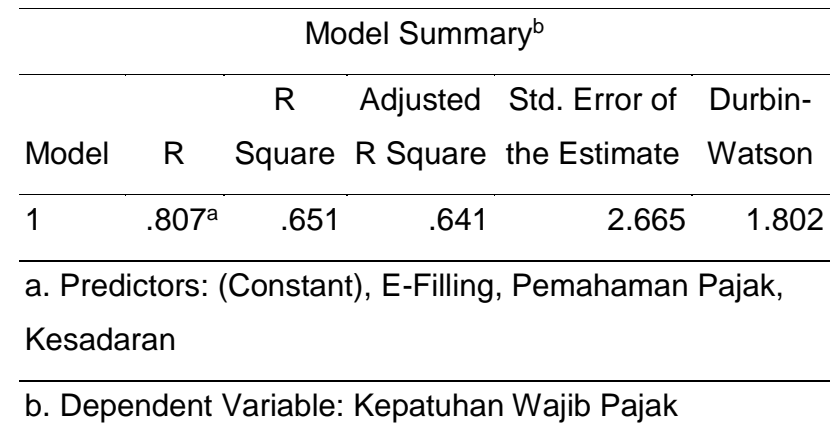

Sumber: data primer yang diolah , Lampiran (2016)

Berdasarkan hasil output SPSS menunjukkan bahwa nilai $\mathrm{R}$ Square $\left(\mathrm{R}^{2}\right)$ sebesar 0,651 dengan jumlah $\mathrm{n}$ penelitian 70 , maka besarnya nilaichi-squarehitung $=70 \times 0,651$ $=45,57$. Nilai ini dibandingkan dengan $\mathrm{c}_{2}$ tabel dengan $\mathrm{df}=70$ dan tingkat signifikansi 0,05 didapat nilai chi-squaretabel sebesar 90.53123. Oleh karena nilai chi-square hitung lebih kecil dari chi-squaretabel maka dapat disimpulkan bahwa model regresi dalam penelitian ini berbentuk linear.

\section{c) Uji Multikolinearitas}

Tabel 3. Hasil Uji Multikolinearitas

\begin{tabular}{llc}
\hline \multicolumn{1}{c}{ Model } & \multicolumn{2}{c}{$\begin{array}{c}\text { Collinearity } \\
\text { Statistics }\end{array}$} \\
\cline { 2 - 3 } & Tolerance & VIF \\
\hline (Constant) & & \\
\hline E-Filling & .420 & 2.381 \\
\hline $\begin{array}{l}\text { Pemahaman } \\
\text { Perpajakan }\end{array}$ & .398 & 2.515 \\
\hline $\begin{array}{l}\text { Kesadaran Wajib } \\
\text { Pajak }\end{array}$ & .382 & 2.616 \\
\hline
\end{tabular}

a. Dependent Variable: Kepatuhan

Sumber: Data yang diolah, Lampiran (2016)

Hasil perhitungan nilai Variance Inflation Factor (VIF) juga menunjukkan nilai VIF kurang dari 10. Jadi, dapat disimpulkan bahwa tidak ada multikolinieritas antar variabel dalam model regresi di penelitian ini.

\section{d) Uji Heteroskedastisitas}

Hasil pengolahan uji heteroskedastisitas dengan menggunakan SPSS Versi 20 adalah sebagai berikut: 


\section{JURNAL NOMINAL / VOLUME V NOMOR 2 / TAHUN 2016}

Scatterplot

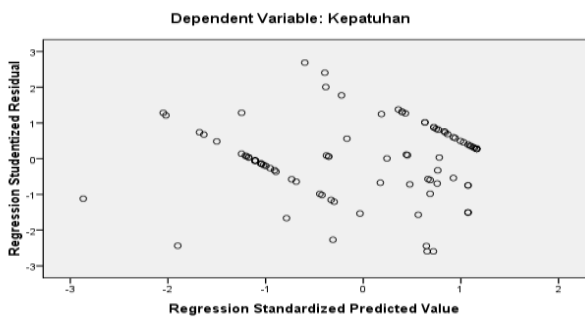

Gambar 2. Uji Heteroskedastisitas

Dari grafik scatterplots terlihat bahwa titik-titik menyebar secara acak serta tersebar di atas maupun di bawah angka 0 (nol) pada sumbu Y. Hal ini dapat disimpulkan bahwa tidak terjadi heteroskedastisitas pada model regresi di penelitian ini, sehingga model regresi tersebut layak dipakai untuk memprediksi variabel dependen Kepatuhan Wajib Pajak berdasarkan masukan variabel independen Penerapan e-filing, Tingkat pemahaman perpajakan dan Kesadaran Wajib Pajak.

\section{Uji Hipotesis}

Dalam penelitian ini, uji hipotesis dilakukan dengan analisis regresi linear sederhana dan analisis regresi linear berganda. Berikut hasil uji hipotesis dengan SPSS 20:

Tabel 4. Uji Hipotesis

\begin{tabular}{lllll}
\hline & Konstanta & Koefisien & $\begin{array}{l}\text { Nilai } \\
\text { Sig }\end{array}$ & Ket \\
& & & 0,000 & Sig \\
\hline $\mathrm{H}_{1}$ & 7,427 & 0,293 & 0,000 & Sig \\
\hline $\mathrm{H}_{2}$ & 8,380 & 0,653 & 0,000 & Sig \\
\hline $\mathrm{H}_{3}$ & 6,373 & 1,184 & 0,000 & $\mathrm{Sig}$ \\
\hline $\mathrm{H}_{4}$ & 2,724 & 0,079 & 0,00 & \\
& & 0,119 & & \\
& & 0,854 & & \\
& & & &
\end{tabular}

Sumber: Data yang diolah, Lampiran (2016)

Berdasarkan tabel diatas dapat dilihat bahwa: $\mathrm{H}_{1}$ diterima dengan nilai koefisien sebesar $0,293, \mathrm{H}_{2}$ diterima dengan nilai koefisien $0,653, \mathrm{H}_{3}$ diterima dengan nilai koefisien 1,184 dan $\mathrm{H}_{4}$ diterima dengan nilai koefisien 0,079, 0,119 dan 0,854.

\section{PEMBAHASAN}

a) Pengaruh Penerapan e-filing terhadap Kepatuhan Wajib Pajak di KPP Pratama Yogyakarta

Hasil penelitian ini mendukung hipotesis pertama yang menyatakan bahwa penerapan e-filing berpengaruh positif terhadap Kepatuhan Wajib Pajak di KPP Pratama Yogyakarta. Nilai koefisien regresi sebesar 0,293 yang memiliki arah positif. Hal ini menunjukkan bahwa semakin baik Penerapan e-filing maka Kepatuhan Wajib Pajak juga akan semakin baik. Selain itu, berdasarkan hasil koefisien korelasi sebesar 0,674 dan koefisien determinasi $\left(r^{2}\right) \quad 0,454$ menunjukkan penerapan e-filing berpengaruh terhadap Kepatuhan Wajib Pajak dan mempengaruhi $45,4 \%$ terhadap Kepatuhan Wajib Pajak. Hasil dari penelitian ini mendukung hasil penelitian dari Sari Nurhidayah (2015) yang menyatakan bahwa $e$-filing berpengaruh terhadap Kepatuhan Wajib Pajak dimana e-filing ini dimoderasi oleh pemahaman 


\section{JURNAL NOMINAL / VOLUME V NOMOR 2 / TAHUN 2016}

Wajib Pajak dalam menggunakan internet.

Penerapan e-filing dapat dilihat dari persepsi Wajib Pajak dalam menggunakan e-filing. Wajib Pajak yang menganggap bahwa e-filing bermanfaat dan memudahkannya dalam melaksanakan kewajiban perpajakan, akan membuat Wajib Pajak merasa puas menggunakan e-filing dan selanjutnya membuat Wajib Pajak semakin patuh. Jadi semakin baik penerapan e-filing maka Kepatuhan Wajib Pajak akan semakin meningkat.

b) Pengaruh tingkat pemahaman perpajakan terhadap Kepatuhan Wajib Pajak di KPP Pratama Yogyakarta

Hasil penelitian ini mendukung hipotesis kedua yang menyatakan bahwa tingkat pemahaman perpajakan berpengaruh positif terhadap Kepatuhan Wajib Pajak di KPP Pratama Yogyakarta. Hal ini dapat dibuktikan dengan nilai $\mathrm{t}$ hitung lebih besar dari t tabel. Nilai $t$ hitung untuk variabel penerapan tingkat pemahaman perpajakan sebesar 8,848 . Nilai ini lebih besar dari $t$ tabel yaitu 1,66 dengan nilai signifikansi sebesar 0,000 lebih kecil dari 0,05. Nilai koefisien regresi sebesar 0,653 yang memiliki arah positif. Hal ini menunjukkan bahwa semakin baik tingkat pemahaman perpajakan maka
Kepatuhan Wajib Pajak juga akan semakin baik. Hasil dari penelitian ini mendukung hasil penelitian sebelumnya, yaitu penelitian yang dilakukan oleh Nirawan Adiasa (2013) yang menunjukan bahwa pemahaman tentang peraturan perpajakan berpengaruh positif terhadap Kepatuhan Wajib Pajak.

Tingkat pemahaman perpajakan dilihat dari seberapa besar Wajib Pajak memahami ketentuan perpajakan yang berlaku. Wajib Pajak yang memiliki tingkat pemahaman perpajakan yang tinggi akan memperkecil tingkat pelanggaran terhadap peraturan pajak dan memperbesar tingkat Kepatuhan Wajib Pajak. Jadi semakin tinggi tingkat pemahaman perpajakan maka semakin tinggi Kepatuhan Wajib Pajak.

c) Pengaruh kesadaran Wajib Pajak terhadap Kepatuhan Wajib Pajak di KPP Pratama Yogyakarta

Hasil penelitian ini mendukung hipotesis ketiga yang menyatakan bahwa kesadaran Wajib Pajak berpengaruh positif terhadap Kepatuhan Wajib Pajak di KPP Pratama Yogyakarta.Hal ini dapat dibuktikan dengan nilai $\mathrm{t}$ hitung lebih besar dari $\mathrm{t}$ tabel.Nilai $\mathrm{t}$ hitung untuk variabel kesadaran Wajib Pajak sebesar 12,664. Nilai ini lebih besar dari $t$ tabel yaitu 1,66 dengan nilai signifikansi sebesar 0,000 lebih kecil dari 0,05. Nilai koefisien regresi sebesar 1,184 yang 


\section{JURNAL NOMINAL / VOLUME V NOMOR 2 / TAHUN 2016}

memiliki arah positif. Hal ini menunjukkan bahwa semakin tinggi kesadaran Wajib Pajak maka Kepatuhan Wajib Pajak juga akan semakin baik. Hasil dari penelitian ini mendukung hasil penelitian dari Restu Mutmainah Marjan (2014) yang menyatakan bahwa kesadaran Wajib Pajak berpengaruh positif dan signifikan terhadap kepatuhan formal wajib pajak.

Kesadaran Wajib Pajak dilihat dari seberapa besar tingkat kedisiplinan dan kemauan Wajib Pajak dalam melaksanakan hak dan kewajibannya sesuai dengan ketentuan peraturan perundang-undangan yang berlaku. Wajib Pajak yang memiliki kesadaran yang tinggi akan membuatnya patuh dalam melaksanakan kewajiban dan hak perpajakkannya. Jadi semakin tinggi kesadaran Wajib Pajak maka Kepatuhan Wajib Pajak akan semakin meningkat.

d) Pengaruh penerapan e-filing, tingkat pemahaman perpajakan dan kesadaran Wajib Pajak terhadap Kepatuhan Wajib Pajak di KPP Pratama Yogyakarta

Hasil penelitian ini mendukung hipotesis keempat yang menyatakan bahwa penerapan e-filing, tingkat pemahaman perpajakan dan kesadaran Wajib Pajak berpengaruh positif terhadap Kepatuhan Wajib Pajak di KPP Pratama Yogyakarta. Hal ini dapat dibuktikan dengan nilai $\mathrm{F}$ hitung lebih besar dari $\mathrm{F}$ tabel.Nilai $F$ hitung adalah sebesar 59.820. Nilai ini lebih besar dari $F$ tabel yaitu 3,94 dengan nilai signifikansi sebesar 0,000 lebih kecil dari 0,05. Hal ini menunjukkan bahwa semakin baik Penerapan e-filling, tingkat pemahaman perpajakan dan kesadaran Wajib Pajak maka Kepatuhan Wajib Pajak juga akan semakin baik.

Hasil dari penelitian ini mendukung pernyataan dari Rochmat (1991:94) dan Salamun (1990:190) yang menyatakan bahwa tingkat pemahaman perpajakan dan kesadaran Wajib Pajak mempengaruhi Kepatuhan Wajib Pajak. Selain itu penelitian ini mendukung penelitian yang dilakukan oleh Sari Nurhidayah (2014) e-filing berpengaruh positif terhadap Kepatuhan Wajib Pajak dan menolak penelitian yang dilakukan oleh Nurul Afia Sari (2013) yang menyatakan bahwa e-spt tidak berpengaruh terhadap Kepatuhan Wajib Pajak.

Penerapan e-filing dilihat dari seberapa baik persepsi Wajib Pajak tentang e-filing, tingkat pemahaman perpajakan dilihat dari seberapa tinggi Wajib Pajak mengerti tentang peraturan perpajakan yang berlaku, sedangkan kesadaran Wajib Pajak dilihat dari seberapa tinggi kedisiplinan dan kemauan Wajib Pajak untuk melaksanakan 


\section{JURNAL NOMINAL / VOLUME V NOMOR 2 / TAHUN 2016}

kewajiban perpajakannya. Wajib Pajak yang merasa puas menggunakan $e$-filing, memahami dengan baik peraturan perpajakan dan memiliki kedisplinan juga kemauan yang tinggi dalam melaksanakan kewajiban perpajakan akan membuat Wajib Pajak tersebut semakin patuh. Jadi semakin baik penerapan e-filing, tingkat pemahaman perpajakan dan kesadaran Wajib Pajak maka Kepatuhan Wajib Pajak juga akan semakin meningkat.

\section{SIMPULAN DAN SARAN}

\section{Simpulan}

Berdasakan hasil pengujian dan pembahasan, dapat ditarik kesimpulan sebagai berikut:

a) Penerapan e-filing berpengaruh positif dan signifikan terhadap Kepatuhan Wajib Pajak di KPP Pratama Yogyakarta. Nilai koefisien regresi yang positif yaitu sebesar 0,293. Koefisien determinasi 0,454 ini berarti penerapa penerapan $e$ filing mempengaruhi Kepatuhan Wajib Pajak sebesar 45,4\%. Besarnya nilai koefisien regresi 0,293 dengan nilai konstanta 7,427. Persamaan garis regresinya adalah $\mathrm{Y}=7,427+0,293 \mathrm{X}_{1}$. Hal ini berarti semakin tinggi Penerapan e-filing maka semakin tinggi Kepatuhan Wajib Pajak.

b) Tingkat pemahaman perpajakan berpengaruh positif dan signifikan terhadap Kepatuhan Wajib Pajak di KPP
Pratama Yogyakarta. Nilai koefisien regresi yang positif yaitu sebesar 0,653. Koefisien determinasi 0,444 berarti tingkat pemahaman perpajakan mempengaruhi Kepatuhan Wajib Pajak sebesar 44,4\%. Persamaan garis regresinya adalah $\mathrm{Y}=8,830+0,653 \mathrm{X}_{2}$. Hal ini berarti semakin tinggi tingkat pemahaman perpajakan maka semakin tinggi Kepatuhan Wajib Pajak.

c) Kesadaran Wajib Pajak berpengaruh positif dan signifikan terhadap Kepatuhan Wajib Pajak di KPP Pratama Yogyakarta. Nilai koefisien regresi yang positif yaitu sebesar 1,184. Koefisien determinasi 0,621 berarti kesadaran Wajib Pajak memepengaruhi Kepatuhan Wajib Pajak sebesar 62,1\%. Persamaan garis regresinya adalah $\mathrm{Y}=6,373+1,184 \mathrm{X}_{3}$. Hal ini berarti semakin tinggi kesadaran Wajib Pajak maka semakin tinggi Kepatuhan Wajib Pajak.

d) Penerapan e-filing, tingkat pemahaman perpajakan dan kesadaran Wajib Pajak berpengaruh positif dan signifikan terhadap Kepatuhan Wajib Pajak di KPP Pratama Yogyakarta. Nilai koefisien regresi yang positif yaitu sebesar 0,293 untuk variabel penerapan $e$-filing, sebesar 0,653 untuk variabel tingkat pemahaman perpajakan sedangkan variabel kesadaran Wajib Pajak sebesar 1,184. Nilai F hitung yang lebih besar dari $\mathrm{F}$ tabel yaitu 59.820 $>$ 3,94. Koefisien determinasi 0,651 hal ini 


\section{JURNAL NOMINAL / VOLUME V NOMOR 2 / TAHUN 2016}

berarti penerapan e-filing, tingkat pemahaman perpajakan dan kesadaran Wajib Pajak mempengaruhi Kepatuhan Wajib Pajak sebesar 65,1\%.

\section{Saran}

Saran yang dapat diberikan sehubungan dengan hasil penelitian dan keterbatasan penelitian adalah sebagai berikut:

a) Direktorat Jenderal Pajak diharapkan mensosialisasikan tata cara penggunaan $e$ filing lewat iklan di kantor pajak terutama untuk pemula. Hal ini dikarenakan rendahnya rata-rata skor yang diberikan responden untuk butir pernyataan variabel $e$-filing pada item kemudahan pengisian SPT bagi pemula.

b) Direktorat Jenderal Pajak sebaiknya lebih menyederhanakan sistem e-filing karena banyak Wajib Pajak yang merasa kesuliatan dalam menggunakan $e$-filing.

c) Penyuluhan pajak perlu ditingkatkan dan difokuskan tentang sanksi perpajakan, karena dalam penelitian ini pernyataan mengenai sanksi perpajakan memiliki rata-rata skor terendah dalam variabel tingkat pemahaman perpajakan.

d) Tingkat kedisiplinan Wajib Pajak perlu ditingkatkan dengan sosialisasi mengenai pentingnya pajak bagi pembangunan negara karena skor pernyataan mengenai kedisiplinan membayar pajak pada variabel kesadaran Wajib Pajak memiliki skor terendah dalam penelitian ini. e) Bagi peneliti selanjutnya sebaiknya lebih memperbesar jumlah sampel dalam penelitian. Hal ini dilakukan agar data yang dihasilakan oleh peneliti selanjutnya lebih akurat.

f) Bagi peneliti selanjutnya yang ingin menggunakan variabel $e$-filing sebaiknya dapat memperluas lokasi penelitian. Hal ini dilakukan agar didapatkan perbandingan hasil penerapan $e$-filing.

\section{DAFTAR PUSTAKA}

Abdul Rahman. (2010). Panduan Pelaksanaan Administrasi Pajak: Untuk Karyawan, Pelaku Bisnis Dan Perusahaan. Bandung: Nuansa.

Anonim.(2014). "Lebih Dari 50\% Wajib Pajak Belum Bayar Pajak".Diaksesmelalui http://www.cnnindonesia.com/ekono mi/20141014175233-78-6372/lebihdari-50-wajib-pajak-belum-bayarpajak/ tanggal 09 November 2015, jam 09.36 WIB

. (2014). "Kesadaran Pajak Orang Indonesia Rendah, 80 Persen Harus Dipaksa". Diakses melalui http://www.ortax.org/ortax/?mod=be rita\&page $=$ show $\& \mathrm{id}=13751 \& \mathrm{q}=\& \mathrm{hl}$ $\underline{m=}$ tanggal 31 Maret 2016, jam 11.00 WIB.

(2015). "Bulan Kedelapan Penerimaan DIY Belum 50\%”. Diakses melalui www.harianjogja.com/read/2015082 6/7/3476/bulan-kedelapanpenerimaan-pajak-diy-belum-50

Pada tanggal 17 september 2015, jam 09.32 WIB. 
- (2015). "Pelajari dan Pahami Sebelum Memilih Terpisah". Diakses melalui

http://www.ortax.org/ortax/?mod=iss ue \&page $=$ show $\&$ id $=70$ Pada tanggal 22 febuari 2016, jam 17.18 WIB.

. (2015). "Tingkat Kepatuhan Wajib Pajak Perorangan Masih Rendah". Diakses melalui http://jogja.tribunnews.com/2015/02/ 09/tingkat-kepatuhan-wajib-pajakperorangan-masih-rendah tanggal 08 November 2015, jam 16.40 WIB.

(2015). "Wajib Pajak Tak Patuh, Jumlah Pelaporan SPT PPh 2015 Anjlok". Diakses melalui http://ortax.org/ortax/?mod=berita\& page $=$ show $\&$ id $=14055 \& \mathrm{q}=\&$ hlm $=$ tanggal 08 November 2015, jam 15.36 WIB.

Diana Sari. (2013). Konsep Dasar Perpajakan. Bandung: Refika Aditama.

Direktorat Jenderal Pajak. (2004). "E-SPT". Diakses melalui www.pajak.go.id pada tanggal 15 September 2015 jam 16.28 WIB.

. (2004). "Apa itu e-filing". Diakses melalui

www.pajakku.com/index.asp?modul e=information \&task=detail \&title $=$ In foeFilingpada tanggal 15 September 2015, Jam 16.30 WIB.

Djoko Muljono. (2007). Pengantar PPh Dan PPh 21 Lengkap Dengan UndangUndang.Yogyakarta: Andi Yogyakarta.

Erly Suandy. (2011). Perencanaan Pajak.Jakarta: Salemba Empat.

Gita Govinda Kirana. (2010). "Analisis Perilaku Penerimaan Wajib Pajak Terhadap Penggunaan E-Filling (Kajian Empiris Di Wilayah Kota
Semarang)".Skripsi. Fakultas Ekonomi Universitas Diponegoro.

Gunawan Setiyaji dan Hidayat Amir.(2005). "Evaluasi Kinerja Sistem Perpajakan di Indonesia."Jurnal Ekonomi Universitas Indonusa Esa Tunggal. Vol. 10, No. 2.

Husein Umar. (2011). Metode Penelitian Untuk Skripsi Dan Tesis Bisnis. Jakarta: PT Raja Grafindo Persada.

Imam Ghozali. (2006). Aplikasi Analisis Multivariate Dengan Program SPSS. Semarang: Undip.

Isroah.(2012). Perpajakan. Yogyakarta: Uny Press.

Mardiasmo. (2011). Perpajakan. Yogyakarta: Andi.

Nasution.(2006). Perpajakan. Jakarta: Bumi Aksara

Nirawan.(2013). "Pengaruh Pemahaman Peraturan Pajak Terhadap Kepatuhan Wajib Pajak Dengan Preferensi Risiko Sebagai Variabel Moderating".Skripsi.Jurusan

Akuntansi Universitas Negeri Semarang.

Novi Purnama Sari.(2014). "Pengaruh Penerapan e-SPT Terhadap Kepatuhan Wajib PajakBadan DalamMelaporkan SPT (Studi Kasus Pada KPP Madya Malang)". Skripsi. Program Studi Perpajakan Universitas Brawijaya.

Nur Indriantoro \& Bambang Supomo.(2009). Metodologi Penelitian Bisnis untuk Akuntansi dan Manajemen.Yogyakarta : BPFE Yogyakarta. 


\section{JURNAL NOMINAL / VOLUME V NOMOR 2 / TAHUN 2016}

Republik Indonesia, Peraturan Menteri Nomor 29/PMK.03/2015 tentang "Pengurangan dan Penghapusan Administrasi Pajak atas Keterlambatan Penyampaian Surat Pemberitahuan, Pembetulan Surat Pemberitahuan dan Keterlambatan Pembayaran Atau Penyetoran Pajak".

Republik Indonesia, Peraturan Menteri Nomor 91/PMK.03/2015 tentang "Pengurangan atau Penghapusan Administrasi Pajak atas Keterlambatan Penyampaian Suaat Pemberitahuan, Pembetulan Surat Pemberitahuan dan Keterlambatan Pembayaran atau Penyetoran Pajak".

,Peraturan Pemerintah Nomor 91 Tahun 2010 tentang "Jenis Pajak Daerah Yang Dipungut Berdasarkan Penetapan Kepala Daerah Atau Dibayar Sendirioleh Wajib Pajak".

Undang-Undang Republik Indonesia Nomor 36 Tahun 2008 tentang Perubahan Keempat Atas UndangUndang Nomor 7 Tahun 1983 tentang "Pajak Penghasilan".

Undang-Undang Republik Indonesia Nomor 16 Tahun 2009 tentang Penetapan Peraturan Pemerintah Pengganti Undang-Undang Nomor 5 Tahun 2008 tentang Perubahan Keempat Atas Undangundang Nomor 6 Tahun 1983 tentang "Ketentuan Umum dan Tata Cara Perpajakan Menjadi Undang-Undang".

Riza Anvillia Putri (2015). "Faktor-Faktor Yang Mempengaruhi Kepatuhan Penyampaian Surat Pemberitahuan (Spt) TahunanWajib Pajak Orang Pribadi (WPOP)(Studi Pada Wajib Pajak Orang Pribadi Di Kpp Pratama Kepanjen)".Journal Ilmiah Mahasiswa FEB.Vol. 3, No. 2.
Restu Mutmainah Marjan. (2014). "Pengaruh Kesadaran Wajib Pajak, Pelayanan Fiskus, Dan Sanksi Pajak Terhadap Tingkat Kepatuhan Formal Wajib Pajak(Studi Di Kantor Pelayanan Pajak Pratama Makassar Selatan)". Skripsi. Jurusan Akuntansi Universitas Hasanuddin.

Rochmat Soemitro. (1991). Asas dan Dasar Perpajakan.Bandung: PT. Eresco.

Safrin Nurmantu. (2005). Pengantar Perpajakan.Jakarta: Granit.

Sari Nurhidayah.(2015). "Pengaruh Penerapan Sistem E-Filling Terhadap Kepatuhan Wajib Pajak Dengan Pemahaman Internet Sebagai Variabel Pemoderasi Pada Kpp Pratama Klaten".Skripsi.Program Studi Akuntansi Universitas Negeri Yogyakarta.

Salamun A.T. (1990). Prospek dan Faktor Penentu Reformasi Perpajakan. Jakarta: Bina Rena Pariwara.

Septia Deni. (2015). "Wajib Pajak Harus Lunasi Kewajiban Tahun Ini". Diakses melalui http://bisnis.liputan6.com/read/2303 156/wajib-pajak-harus-lunasikewajiban-di-tahun-ini Pada tanggal 24 November, jam 05.00 WIB.

Siti Resmi. (2009). Perpajakan Teori Dan Kasus. Jakarta: Salemba Empat.

Soemarso. (2007). Perpajakan. Jakarta: Salemba Empat.

Sri Putri Tita Mutia (2014) "Pengaruh Sanksi Perpajakan, Kesadaran Perpajakan, Pelayanan Fiskus, Dan Tingkat Pemahaman Terhadap Kepatuhan Wajib Pajak Orang Pribadi (Studi Empiris Pada Wajib Pajak Orang Pribadi Yang Terdaftar Di Kpp 
Pratama Padang)". Journal Akuntansi.Vol. 2, No. 1.

Sugiyono.(2008). Statistika Untuk

Penelitian. Bandung: Alfabeta.

Sugiyono \& Agus Susanto. (2015). Cara Mudah Belajar SPSS \& LISREL Teori Dan Aplikasi Untuk Analisis Data Penelitian. Bandung: Alfabeta

Sutrisno Hadi. (2004). Analisis Regresi. Yogyakarta: Andi Offset.

Uma Sekaran. (2011). Metode Penelitian Untuk Bisnis. Jakarta: Salemba Empat. 